lican, Michigan). Together with Senator Orrin Hatch (Republican, Utah), Abraham has co-sponsored a bill to raise the cap on $\mathrm{H}$ $1 \mathrm{~B}$ visas to 195,000 for 2000, 2001 and 2002. Colleges and universities would be exempt.

In the House of Representatives, David Dreier (Republican, California) and Zoe Lofgren (Democrat, California) have introduced a bill that would up the quota to 200,000 for 2001, 2002 and 2003. But rather than exempting colleges and universities, the bill would set aside a certain number of visas for them, as well as for applicants educated to levels of Master or the equivalent. Both bills contain provisions for educating and training US workers.

The complication in all of this is a bill introduced by Representative Lamar Smith (Republican, Texas), which would put no limits on $\mathrm{H}-1 \mathrm{~B}$ visas over the next three years. However, an aide says Smith insists that the bill be balanced and include some provisions that are good for US workers. Compa- nies would need to show, for example, that the median wage of their US employees had increased over the previous year. There is also a $\$ 40,000$ annual minimum wage requirement for $\mathrm{H}-1 \mathrm{~B}$ workers, although colleges and universities would be exempted. In addition, the bill contains measures to protect against abuses of the system by so-called job shops set up solely to hire $\mathrm{H}-1 \mathrm{~B}$ workers. Moreover, work experience would no longer be an acceptable substitute for a degree.

"Even though on the face of it he [Smith] eliminates the cap altogether, all these other provisions would serve to restrict the usefulness of the programme," says Jeanne Butterfield, executive director of the American Immigration Lawyers Association. “A \$40,000 salary floor ... may sound like a nice round number but it doesn't take into account the particularities of different pockets of the country where that might not be an appropriate equivalent wage." Butterfield says the association supports the Hatch-Abraham and

\title{
The economic impact of Silicon Valley's immigrant entrepreneurs
}

A study called Silicon Valley's New Immigrant Entrepreneurs suggests that, rather than simply displacing native-borne workers, as is sometimes argued, many highly skilled immigrants make significant contributions to the economic development of the region.

The study, conducted for the Public Policy Institute of California by AnnaLee Saxenian of the department of city and regional planning at the University of California, Berkeley, showed that foreign-born workers account for about a third of the skilled scientific and engineering workforce in Silicon Valley, with Indians and Chinese predominating. Moreover, Saxenian found that in 1998, Chinese and

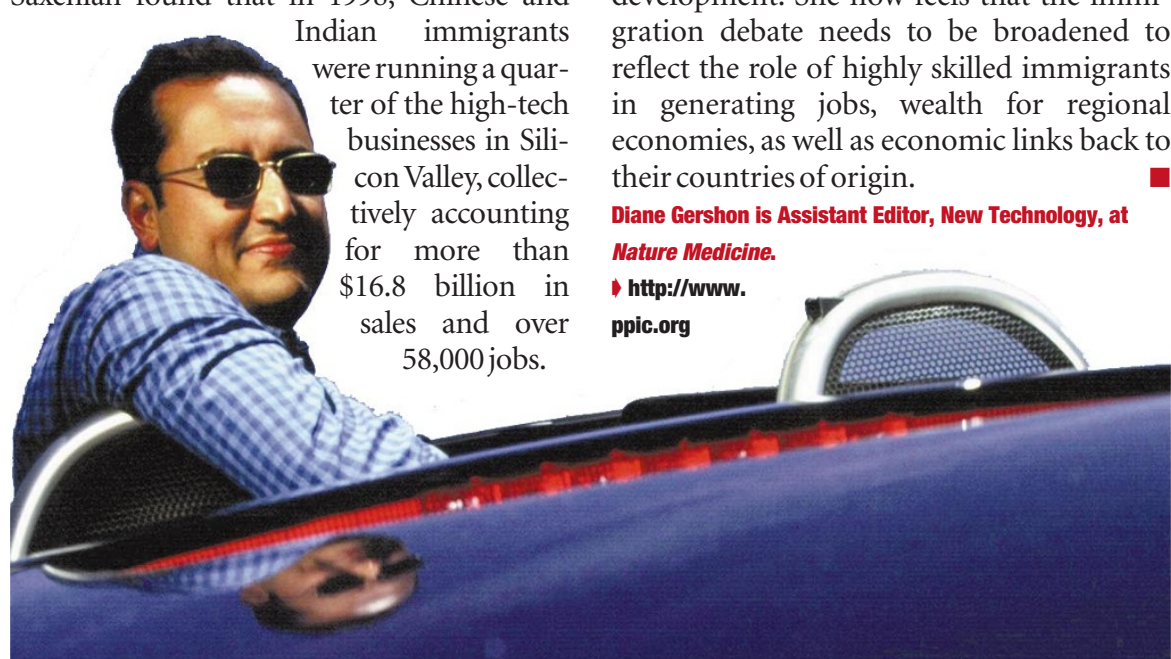

Rich rewards: Silicon Valley has benefited greatly from immigrant entrepreneurs such as Sabeer Bhatia.
Dreier-Lofgren initiatives but she feels that Smith's bill is a "political ploy to try and undercut Dreier-Lofgren". As this is a bipartisan effort, Republicans would be unable to claim total credit for it should it pass, she says.

\section{Breaking the bottleneck}

The Biotechnology Industry Organization (BIO), a trade association representing 920 of the estimated 1,300 US biotechnology companies, has also thrown its weight behind the Hatch-Abraham and Dreier-Lofgren bills. "The bottlenecks on personnel can be quite damaging," says Chuck Ludlam, BIO's vicepresident for government relations. According to the BIO, there are 153,000 people employed in the US biotech industry, about 10 per cent of whom have $\mathrm{H}-1 \mathrm{~B}$ visas.

Robert Tjian, a professor of molecular and cell biology at the University of California, Berkeley, understands about the tight labour market. He co-founded the biotech company Tularik in San Francisco about 10 years ago, and says that Tularik" is constantly in the market to hire more chemists".

Although the current policy debate about US immigration is focused almost entirely on highly skilled workers and the $\mathrm{H}-1 \mathrm{~B}$ visa quota, there is a larger issue here, says Representative Smith's aide. When Congress began debating the $\mathrm{H}-1 \mathrm{~B}$ issue again last year, Smith called it "the tip of the workforce iceberg", referring to the mismatch between the skills of permanent immigrants admitted to the United States and the needs of the workforce. "The reason why we are spending so much time and energy on temporary, basically foreign guest worker visas, is that our legal immigration system is not meeting the nation's needs," says Smith's aide. Today, 35 per cent of the almost one million legal immigrants admitted to the United States each year lack a high-school education, Smith's aide notes. At the same time, 90 per cent of new jobs require more than a highschool diploma.

"Historically in this country in times of economic success ... people are willing to be quite generous in terms of immigration policy: in times of recession and hardship, that opinion turns around," says Butterfield.

Few would argue that more needs to be done in education and training to encourage more Americans to go into computer sciences, engineering and other high-tech disciplines. But the high-tech industry argues that there are job vacancies that need filling today, and this is increasing pressure on Congress to ease restrictions on temporary foreign workers as a stop-gap measure. Although it may help with critical labour shortages in certain high-tech sectors, "it's a short-term fix for a long-term challenge”, says Senator Abraham's aide.

http://www.senate.gov/ abraham

| http://www.house.gov/dreier

http://www.house.gov/lamarsmith

| http://www.comptia.org 